\title{
ASSESSMENT OF TRIP EXPERIENCE FROM CHINESE TOURISTS' PERSPECTIVES ON INDONESIA TOURISM
}

\author{
Filda RAHMIATI* \\ President University, Ki Hajar Dewantara, Faculty of Business, Cikarang, Indonesia, e-mail: filda.rahmiati@president.ac.id \\ Mohammed Hariri BAKRI \\ Universiti Teknikal Melaka Malaysia, Faculty of Technology Management \\ \& Technopreneurship, Hang Tuah Jaya, Meaka, Malaysia, e-mail: hariri@utem.edu.my \\ Fu SHUYUAN \\ President University, Faculty of Business, Ki Hajar Dewantara, Cikarang, Indonesia, e-mail: fu.shuyuan@ student.president.ac.id
}

\begin{abstract}
Citation: Rahmiati, F., Bakri, M.H., \& Shuyuan, F. (2021). ASSESSMENT OF TRIP EXPERIENCE FROM CHINESE TOURISTS' PERSPECTIVES ON INDONESIA TOURISM. GeoJournal of Tourism and Geosites, 38(4), $1083-1088$. https://doi.org/10.30892/gtg.38413-747
\end{abstract}

\begin{abstract}
With China's rapid economic growth and improved standard of living, travel and tourism are increasingly becoming the first choices for vacation activities. The purpose of this research is to assess the trip experience on destination loyalty through tourist satisfaction of Chinese tourists who visited Indonesia tourism. The quantitative research method was used and the primary data collected using questionnaire to 158 respondents of Chinese tourists who visited Indonesia analyzed using Partial Least Squares Structural Equation Modeling (PLS-SEM). The study indicates that 6 of the 7 hypotheses are accepted. As a result, accommodation mediated by tourist satisfaction has no significant effect on destination loyalty. The impact of trip experience on destination loyalty mediated by tourist satisfaction accounted for 64.4 percent. This study demonstrates how Chinese tourists evaluate their trip experiences of Indonesia tourism. Transportation was discovered to have the greatest impact, whereas need to be improved in order to create destination loyalty.
\end{abstract}

Key words: accommodation, excursions, transportation, trip experience, tourist satisfaction, destination loyalty

\section{INTRODUCTION}

Tourism is a thriving industry these days. With the expansion of the global economy, tourism has emerged as the pillar industry with the highest income in the majority of nations. It is the global engine of employment generation (Edgell, 2019). According the World Travel and Tourism Council's (WTTC) latest annual research, conducted in collaboration with the Oxford Institute for Economic Research, tourism grew by 3.5 percent in 2019, outpacing global economic growth by 2.5 percent for the ninth consecutive year (WTTC, 2019). Indonesia does as well; because as travel industry in Indonesia has developed, the foreign exchange earnings from tourism has increased annually (Jaelani et al., 2020) also leads to the development of related businesses, especially tourism supporting businesses. It has solved a large number of people's employment problems. Over the years, Indonesia has made tourism the focal point of its economic development, and it has achieved great success (Ollivaud, 2019). China has become one of the world's largest markets, as well as Indonesia's second biggest foreign tourist market after Malaysia (Arlt, 2013). With China's rapid economic growth, standard of living has improved greatly, and so as a lifestyle has shifted, travel and tourism are becoming the first options for people's holiday activities (Richards, 2018). According to a report from the China National Tourism Administration, China ranks first in the world of outbound trips in the first half of 2017, with 62 million trips (Wei et al., 2017). The World Tourism Organization (WTO) expects that Chinese tourists could become one of the world's main tourist countries of origin by 2020 (Sartorelli, 2019). Southeast Asian countries are also attempting to entice Chinese tourists. Thailand, Vietnam, Singapore, Malaysia, Indonesia, and the Philippines are among the top 10 most popular destinations in the world (Liu, 2017). The number of Chinese travelers keeps growing, the number of Chinese tourists visiting Indonesia has increased the most rapidly, surpassing Malaysia and Singapore. However, the growth of Chinese tourists has slowed. In 2019, approximately 2 million Chinese tourists visited Indonesia, accounting for $12 \%$ of total foreign tourists (Ollivaud, 2019). Thus, study on trip experience of Chinese tourists who visited Indonesia should be explored in effort to expand future visitors by returning, as well as recommends others as a result of satisfaction.

Tourism satisfaction, according to Ramseook-Munhurrun (2015), is essential to the future viability of tourist destinations. Tourists who are satisfied with their experience will return and recommend it to others. Tourist satisfaction is a determinant of destination loyalty and would be based on tourists' experience, starting from transportation from their home country to the destination, as well as accommodation and excursion activities, while traveling (Rahmiati et al., 2019). Thus, tourists have a trip experience when they engaged in tourism activities and consume tourism products or services.

\footnotetext{
* Corresponding author
} 
Those experiences can boost a desire to return. Positive feedback are generated as a result of offering satisfying tourism goods and services, which increases loyalty (Da Costa Mendes et al., 2010). As a result, Sangpikul (2018) mentioned travel experience associated with people to destination loyalty was shown to be significant. Additionally, Ramesh and Jaunky (2021) mentioned that satisfaction increases destination loyalty allowing businesses to attract more tourists.

Thus, transportation, accommodation, and excursion activities all play an important role in tourist satisfaction and intent to return (Agyeiwaah, 2019). This study explores the tourist satisfaction and destination loyalty of Chinese tourists who visited Indonesia tourism based on trip experience of transportation, accommodation and excursions.

\section{LITERATURE REVIEW AND HYPOTHESIS DEVELOPMENT}

\section{Destination Loyalty}

Customer loyalty can be defined as the customers having a long-term commitment to repurchase the same product or service at a tolerance of price. In addition, customer loyalty linked to the aim of returning and recommending it to others (Liang, 2008; Xue and Yang, 2008; Wahyuningsih, 2012; Amoah et al., 2016; Chiu et al., 2016; Danurdara and Hidayah, 2016; Gallarza et al., 2016). Destination loyalty means a consistent source of income and an increase in the destination's economic advantages. Loyal behavior of tourists means lower costs than attracting new customers (Yasami et al., 2020). As a result, tourist destinations compete for repeat visits from tourists. It is the best predictor of post-visit behavior in terms of destination loyalty. Study done by Sangpikul (2018) approved that travel experience directly affects tourist satisfaction, and also indirectly affects destination loyalty through tourist satisfaction as a mediating variable whereby tourist satisfaction as the important mediating variable (full mediation role) between travel experience and destination loyalty (Figure 1). A high level of tourist satisfaction should be targeted in addition to having a good travel experience at the destination to encourage tourist revisits. Tourists who have had a positive travel experience and are satisfied with the destination's attributes are more likely to return. Also, a memorable tourism experience, through satisfaction, is a good predictor of destination loyalty (Stavrianea and Kamenidou, 2021).

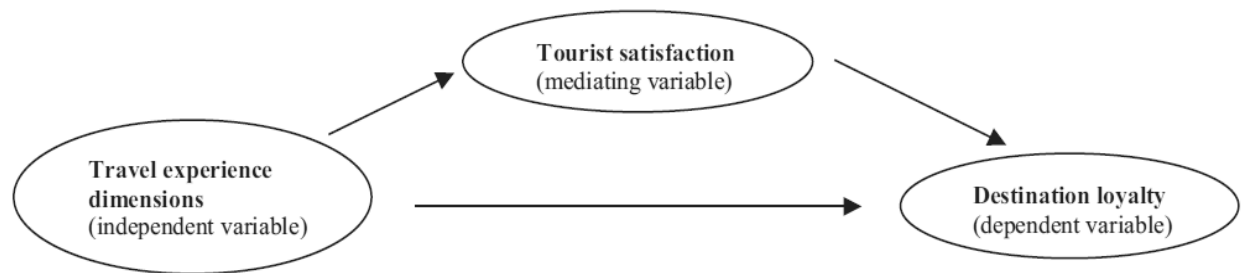

Figure 1. Travel experience dimensions on tourist satisfaction and destination loyalty (Source: Sangpikul, 2018)

\section{Tourist Satisfaction}

Tourist satisfaction in the tourism industry is the result of a comparison of tourists' expectations of the destination and their on-the-spot perception after arriving at the destination. It will influence the choice of destination, consumption of tourism products and services, whether or not to return, and whether or not it is recommended to friends and relatives (Ardani et al., 2019). Tourist satisfaction is developed from customer satisfaction and is considered to be the main variable for maintaining competitive business (Abubakar and Mavondo, 2014). Tourist satisfaction is the result of a variety of factors, including the expectations generated during past travel and the tourist's perception of the services received (González-Rodríguez, 2020).

\section{Trip Experience}

During the trip experience phase customers purchase tourism items such as inbound and outbound transportation, accommodation during the journey, and a variety of tourism experiences known as excursions. The first sub-sector is transportation, which is divided into international and national transport. International air carriers are the most common mode of international transportation (Christian et al., 2011b). Depending on the inbound country, local transportation is also available. Inbound countries have their own transportation actors who coordinate and collaborate with foreign logistics firms. Tourism organizations may equip and invest in more modern and comfortable modes of transportation. Tourist destinations must collaborate with transportation companies to provide more transportation options to tourist attractions, allowing visitors to have a more enjoyable experience (Giao et al., 2021).

After transportation, accommodation could see a place to stay and a place to eat. This phase explains various types of accommodations, such as hotels, boutique hotels, motels, apartments, resorts and many more. Lastly, excursion activities are experienced by tourists. These are natural tourism, entertainment, festival, and also shopping. Besides, tourist's experience is felt when tourists are involved in the tourism activities during the trip; consuming tourism products or services. Those experiences can contribute to a desire to return. Positive feedback are generated as a result of offering the best tourism goods and services, which increases loyalty (Da Costa Mendes et al., 2010). Those activities during the trips experience are measured by the efficiency (Noor et al., 2020) whereby functional benefit experienced by the customer such as time saving. In addition, personnel service quality is important in tourism destination. Competent, helpful, friendly, kind, and knowledgeable personnel are needed today as customers want to be better informed in making selection (Rahman et al., 2016).

Based on the prior discussions, the following hypotheses were proposed in this study:

H1: Transportation has a significant impact on the Chinese tourist satisfaction visiting Indonesia

$\mathrm{H} 2$ : Accommodation has a significant impact on the satisfaction of Chinese tourists visiting Indonesia

H3: Excursions have a significant impact on the satisfaction of Chinese tourists visiting Indonesia

H4: Tourist Satisfaction has a significant impact on the destination loyalty 
H5: Transportation has a significant impact on destination loyalty mediated by tourist satisfaction of Chinese tourists visiting Indonesia

H6: Accommodation has a significant impact on destination loyalty mediated by tourist satisfaction of Chinese tourists visiting Indonesia

H7: Excursions have a significant impact on destination loyalty mediated by tourist satisfaction of Chinese tourists visiting Indonesia

\section{RESEARCH METHOD}

The study used a quantitative research method to examine the impact of trip experiences such as transportation, lodging, and excursions on loyalty as mediated by satisfaction. The data collection using primary data were collected through online questionnaire to Chinese tourists who had previously visited Indonesia within three weeks of data collection period. A non-probability sampling designed for this study. A convenience sampling was used to get the sample. The study's sample size were 158 responses. Questions were graded using a Likert scale of one to seven points. Smart-PLS version 3 data analysis software was used in the study. For transportation, five items were adopted from Setyanto and Pangestuti (2019), five items were adopted from Nugroho et al., (2016), and five items were adopted from Gaffar et al. (2011); Prakash and Chowdhary (2010); Ratminingsih et al. (2018), and Salazar (2013). Five items from Sumaedi et al (2014), Budiman et al (2014), Cholik (2017), and Khuong and Ha (2014) were used to assess Satisfaction (2014). Five items adapted from Khuong and Ha (2014), Gallarza et al (2016), and Liang (2008) were used to assess loyalty.

\section{RESULTS AND DISCUSSION}

\section{Demographic profile of respondents}

The demographic profile of the respondents is divided into gender, age group, time visit, and traveling companions. Gender distribution among respondents is nearly equal, with males accounting for 53\% and females accounting for $47 \%$. The majority of respondents (33\%) are between the ages of 21 and 30, followed by 31-40 years (28\%), 41-50 years (20\%), 20 years $(15 \%)$, and $>50$ years $(6 \%)$. More than half of the respondents $(54 \%)$ are first-time visitors, followed by $2-4$ times $(39 \%)$ and 7 percent visiting Indonesia more than 5 times. Most tourists visiting Indonesia with tour groups account for $30.3 \%$, tourists visiting Indonesia with families account for $29.3 \%$, tourists visiting Indonesia with relatives and friends account for $23.2 \%$, and tourists visiting Indonesia alone account for $17.2 \%$.

\section{Assessment of Measurement Model}

The outer loadings in the study's measurement model are good enough to fit into the construct (Table 1 and Figure 2). However, should be higher than 0.60, there are two constructs that are less than 0.6, so E1 and CTS3 were deleted. The study's outer loadings for transportation range from 0.669 to 0.760 . Loadings for accommodation range from 0.740 to 0.784. The outer loadings for excursion ranged from 0.637 to 0.780 . Outer loadings for satisfaction range from 0.635 to 0.755 . Lasty, loadings for loyalty range from 0.695 to 0.818 .

Table 1. Construct Validity and Reliability

\begin{tabular}{|c|c|c|c|}
\hline Construct & Loading & $\begin{array}{l}\text { Composite } \\
\text { Reliability } \\
\end{array}$ & \begin{tabular}{|c|}
$\begin{array}{c}\text { Average Value } \\
\text { Extracted }\end{array}$ \\
\end{tabular} \\
\hline Transportation & & \multirow{6}{*}{0.844} & \multirow{6}{*}{0.521} \\
\hline T1 & 0.669 & & \\
\hline $\mathrm{T} 2$ & 0.735 & & \\
\hline T3 & 0.721 & & \\
\hline $\mathrm{T} 4$ & 0.760 & & \\
\hline T5 & 0.719 & & \\
\hline Accommodation & & \multirow{6}{*}{0.878} & \multirow{6}{*}{0.590} \\
\hline A1 & 0.740 & & \\
\hline $\mathrm{A} 2$ & 0.770 & & \\
\hline A3 & 0.784 & & \\
\hline $\mathrm{A} 4$ & 0.778 & & \\
\hline $\mathrm{A} 5$ & 0.768 & & \\
\hline Excursion & & \multirow{5}{*}{0.808} & \multirow{5}{*}{0.515} \\
\hline E2 & 0.748 & & \\
\hline E3 & 0.780 & & \\
\hline $\mathrm{E} 4$ & 0.696 & & \\
\hline E5 & 0.637 & & \\
\hline Satisfaction & & \multirow{5}{*}{0.802} & \multirow{5}{*}{0.504} \\
\hline CTS1 & 0.727 & & \\
\hline CTS2 & 0.635 & & \\
\hline CTS4 & 0.718 & & \\
\hline CTS5 & 0.755 & & \\
\hline Destination Loyalty & & \multirow{6}{*}{0.883} & \multirow{6}{*}{0.602} \\
\hline TL1 & 0.695 & & \\
\hline TL2 & 0.792 & & \\
\hline TL3 & 0.818 & & \\
\hline TL4 & 0.778 & & \\
\hline TL5 & 0.793 & & \\
\hline
\end{tabular}

Table 2. Discriminant validity Heterotrait-Monotrait Ratio (HTMT)

\begin{tabular}{|c|c|c|c|c|c|}
\hline & $\begin{array}{l}\text { Accommo- } \\
\text {-dation }\end{array}$ & Excursions & $\begin{array}{c}\text { Destination } \\
\text { Loyalty }\end{array}$ & $\begin{array}{c}\text { Tourist } \\
\text { Satisfaction }\end{array}$ & $\begin{array}{c}\text { Transpor } \\
\text {-tation }\end{array}$ \\
\hline $\begin{array}{c}\text { Accommo } \\
\text {-dation }\end{array}$ & & & & & \\
\hline Excursions & 0.476 & & & & \\
\hline $\begin{array}{c}\text { Destination } \\
\text { Loyalty }\end{array}$ & 0.619 & 0.467 & & & \\
\hline $\begin{array}{c}\text { Tourist } \\
\text { Satisfaction }\end{array}$ & 0.489 & 0.538 & 0.710 & & \\
\hline $\begin{array}{c}\text { Transpor } \\
\text {-tation }\end{array}$ & 0.519 & 0.458 & 0.725 & 0.686 & \\
\hline
\end{tabular}

Table 3. The direct and indirect impact of the study

\begin{tabular}{|c|l|c|c|c|}
\hline $\begin{array}{c}\text { Hypo } \\
\text {-thesis }\end{array}$ & \multicolumn{1}{|c|}{ Relationship } & $\begin{array}{c}\text { T } \\
\text { value }\end{array}$ & P value & $\begin{array}{c}\text { Interpre } \\
\text {-tation }\end{array}$ \\
\hline $\mathrm{H}_{1}$ & Transportation -> Tourist Satisfaction & 4.572 & 0.000 & Significant \\
\hline $\mathrm{H}_{2}$ & Accommodation -> Tourist Satisfaction & 1.986 & 0.048 & Significant \\
\hline $\mathrm{H}_{3}$ & Excursions -> Tourist Satisfaction & 2.297 & 0.022 & Significant \\
\hline $\mathrm{H}_{4}$ & $\begin{array}{l}\text { Tourist Satisfaction -> Destination } \\
\text { Loyalty }\end{array}$ & 2.462 & 0.014 & Significant \\
\hline $\mathrm{H}_{5}$ & $\begin{array}{l}\text { Transportation -> Tourist Satisfaction-> } \\
\text { Destination Loyalty }\end{array}$ & 2.220 & 0.027 & Significant \\
\hline $\mathrm{H}_{6}$ & $\begin{array}{l}\text { Accommodation-> Tourist Satisfaction } \\
\text {-> Destination Loyalty }\end{array}$ & 1.433 & 0.152 & $\begin{array}{c}\text { Not } \\
\text { Significant }\end{array}$ \\
\hline $\mathrm{H}_{7}$ & $\begin{array}{l}\text { Excursions -> Tourist Satisfaction-> } \\
\text { Destination Loyalty }\end{array}$ & 2.706 & 0.039 & Significant \\
\hline
\end{tabular}


As shown in Table 1, Average Value Extracted for five variables shown in acceptable range (minimum requirement is 0.50) from 0.504 to 0.602 . And also, the value of Composite Reliability is greater than 0.7. The next test is to test the discriminant validity through the evaluation of the HTMT value. According to Henseler (2015), if the HTMT value is lower than 0.90 , the validity of the discrimination between the two reflective structures is established (Table 2).

\section{Assessment of Structural Model}

The diagram in Figure 2 depicts the structural model of the study. The bootstrapping method was used in Smart PLS 3 to determine the direct effects of variables. This study's direct relationship standardized into three: the impact of trip experience (transportation, lodging, and excursions) on satisfaction, and the impact of satisfaction on loyalty. They also proposed an indirect relationship, which is the role of satisfaction as a mediator between trip experience (transportation, accommodation, and excursion) and loyalty.

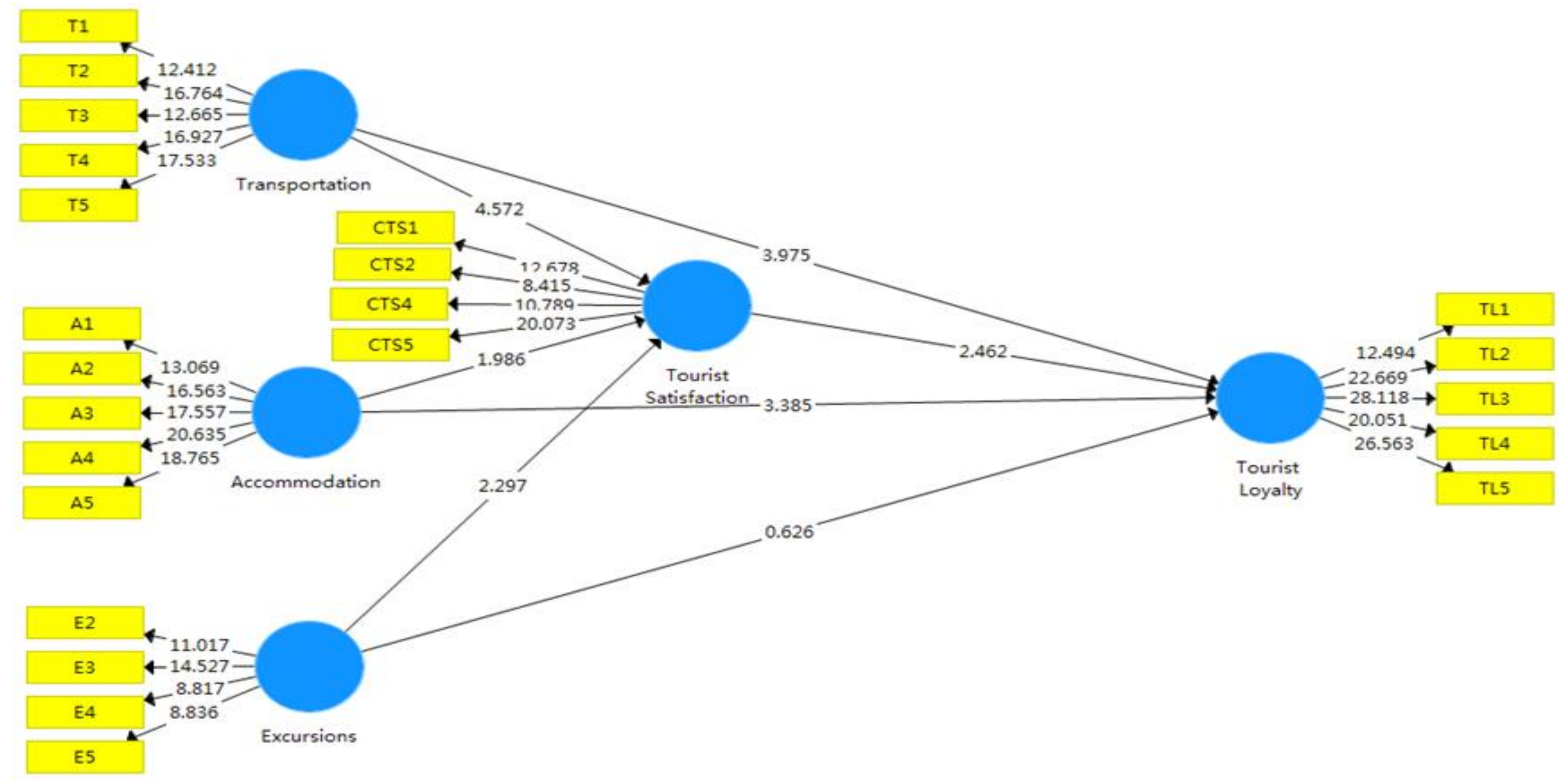

Figure 2. Structural Model of the Study

As shown in Table 3, transportation $(\mathrm{T}$ value $=4.572, \mathrm{p}$ value $=0.000)$, accommodation $(\mathrm{T}$ value $=1.986, \mathrm{p}$ value $=$ $0.048)$ and excursion $(\mathrm{T}$ value $=2.297, \mathrm{p}$ value $=0.022)$ have significant impact on satisfaction. Besides, satisfaction also has a significant impact on loyalty $(\mathrm{T}$ value $=2.462$, $\mathrm{p}$ value $=0.014)$. Table 3 also shows the results of the mediating effects of the study of satisfaction as a mediating variable between trip experience (transportation, accommodation, and excursion) and loyalty. It found out that satisfaction plays a significant mediating role on transportation $(\mathrm{T}$ value $=2.220, \mathrm{p}$ value $=0.027)$, accommodation $(\mathrm{T}$ value $=1.433$, $\mathrm{p}$ value $=0.152)$, and excursion $(\mathrm{T}$ value $=2.706, \mathrm{p}$ value $=0.039)$.

The internal model can be evaluated by observing the value of $\mathrm{Q}^{2}$. The $\mathrm{Q}^{2}$ represents a measure of how well the path model can predict the originally observed values (Hair et al., 2017). In the table, it shows SSO as the sum of the squared observations, SSE the sum of the squared prediction errors, and the last column ( $1-\mathrm{SSE} / \mathrm{SSO})$ the final value of $\mathrm{Q}^{2}$, which we interpret to judge the model's predictive relevance with regard to each endogenous construct. The value of $\mathrm{Q}^{2}$ of .02 represents a "small" effect size, .15 represents a "medium" effect size, and .35 represents a "high" effect size. the $Q^{2}$ values show 0.644 of all endogenous constructs are considerably above zero. These results provide clear support for the model's predictive relevance regarding the endogenous latent variables. This means that the key constructs of transportation, accommodation and excursions as the highest relevance based on high effect size to explain the endogenous latent variable(s) in the structural model accounted for $64.4 \%$, which illustrates by tourist satisfaction on destination loyalty.

\section{CONCLUSION}

The result found that all aspects in trip experience (transportation, accommodation, and excursion) had a direct impact on satisfaction. Transportation is an indispensable part of the tourism industry, and the quality of available and destination transportation will affect the experience and overall satisfaction of tourists. Next, accommodation standards are also important determinant of accommodation satisfaction, as well as satisfaction with prices, facilities and services, and overall satisfaction with accommodation. This research has similar result with Chatzigeorgiou (2017). Last, excursions have a significant impact on tourist satisfaction having similar result with Sangpikul (2018). This research shows that short-distance excursions are an indispensable part of tourism activities. The attitude of the tour guide affects the mood of tourists. The professional level of the tour guide determines whether the tourism activities go smoothly. The historical features and beautiful scenery of the scenic spots are the main tourism purpose, tourist participation in excursion is the core of perceived value and reasonable price, which can improve tourist satisfaction.

A direct relationship is satisfaction and loyalty, this study found similar result with Lee (2011) who mentioned that there is a positive impact of tourist satisfaction and loyalty. Supported by Rahmiati et al. (2020), foreign tourists who are pleased 
with the Indonesia tourism products will undoubtedly return to Indonesia in the future, try more tourist products and services, say positive things about Indonesia, and recommend it to friends and family. Thus, the higher the tourist satisfaction, the higher the loyalty, and this satisfaction will make the tourist return and recommend it to others. This study has similar result with Yamashita and Takata (2021) as the more loyal international tourists feel toward the destination, the more engaged with and familiar they are with the tourism products they have previously visited the destination.

For indirect impact of this study, the provision of appropriate transportation can change the interest of tourists in destinations. Transportation is providing mobility for tourists in the destination, and the experience of tourists in public transportation services may affect the satisfaction of tourists and thus affect the loyalty of tourists. According to the results, accommodation was found not to have significant impact on loyalty when mediated by satisfaction. The lowest t-value was accommodation based on hotel reservations. Most Chinese tourists find it difficult to book a room before visiting Indonesia. The hotel reservation was to be problematic for tourists to stay in Indonesia, which affects the satisfaction and loyalty of tourists. Last result, tourist loyalty can be built by satisfied tourists in excursion.

If Chinese tourists are satisfied with excursion, Chinese tourists will recommend their satisfaction on Indonesia tourism to others. Coban (2012) supported the result that excursion through intermediary visitor satisfaction has a positive and significant impact on loyalty. This study suggests that the importance of the quality of products and services of the trip experience on tourist destination loyalty is mediated by tourist satisfaction, which can create a competitive advantage for Indonesia tourism (Rahmiati et al., 2020). A precise information on tourism products must be available respectively offline and online to avoid miscommunication, such as the availability of adequate transportation, and also the availability of accommodation as well as tourist products.

\section{ACKNOWLEDGEMENTS}

We acknowledge that this research was funded President University, Indonesia. Also, the authors expand their gratitude to Universiti Teknikal Malaysia Melaka, Malaysia for the continuous support of this research.

\section{REFERENCES}

Abubakar, B., \& Mavondo, F. (2014). Tourism Destinations: Antecedents to Customer Satisfaction and Positive Word-of-Mouth. Journal of Hospitality Marketing and Management, 23(8), 833-864. https://doi.org/10.1080/19368623.2013.796865

Agyeiwaah, E. (2019). Exploring the relevance of sustainability to micro tourism and hospitality accommodation enterprises (MTHAEs): Evidence from home-stay owners. Journal of Cleaner Production, 226, 159-171. https://doi.org/10.1016/j.jclepro.2019.04.089

Amoah, F., Radder, L., \& van Eyk, M. (2016). Perceived experience value, satisfaction and behavioural intentions: A guesthouse experience. African Journal of Economic and Management Studies, 7(3), 419-433. https://doi.org/10.1108/AJEMS-10-2015-0121

Ardani, W., Rahyuda, K., Giantari, I.G.A.K., \& Sukaatmadja, I.P.G. (2019). Customer Satisfaction and Behavioral Intentions in Tourism: A Literature Review. International Journal of Applied Business and International Management, 4(3), 84-93.

Arlt, W.G. (2013). The second wave of Chinese outbound tourism. Tourism Planning \& Development, 10(2), 126-133. https://doi.org/10.1080/21568316.2013.800350

Budiman, A., Anantadjaya, S.P.D., \& Prasetyawati, D. (2014). Does Job Satisfaction Influence Organizational Citizenship Behavior? An Empirical Study in Selected 4-Star Hotels in Jakarta, Indonesia. RIBER: Review of Integrated Business and Economics Research, 3(1), 130-149. Available at SSRN. https://ssrn.com/abstract=2406800

Chatzigeorgiou, C., \& Simeli, I. (2017). Perception of service quality in agrotourism accommodations: Impact on guest loyalty and revisit intentions. Journal of Tourism, Heritage \& Services Marketing, 3(1), 33-41. http://dx.doi.org/10.5281/zenodo.401375

Chin, C.H., Law, F.Y., Lo, M.C., \& Ramayah, T. (2018). The impact of accessibility quality and accommodation quality on tourists' satisfaction and revisit intention to rural tourism destination in Sarawak: The moderating role of local communities' attitude. Global Business and Management Research, 10(2), 115-127.

Chiu, W., Zeng, S., \& Cheng, P.S.T. (2016). The influence of destination image and tourist satisfaction on tourist loyalty: a case study of Chinese tourists in Korea. International Journal of Culture, Tourism and Hospitality Research, 10(2), 223-234. https://doi.org/ 10.1108/IJCTHR-07-2015-0080

Cholik, M.A. (2017). The development of tourism industry in Indonesia: Current problems and challenges. European Journal of Research and Reflection in Management Sciences, 5(1), 49-59.

Christian, M., Fernandez-Stark, K., Ahmed, G., \& Gereffi, G. (2011). The tourism global value chain: Economic upgrading and workforce development. G. Gereffi, K. Fernandez-Stark, \& P. Psilos, Skills for upgrading, Workforce development and global value chains in developing countries, 276-280.

Coban, S. (2012). The effects of the image of destination on tourist satisfaction and loyalty: The case of Cappadocia. European Journal of Social Sciences, 29(2), 222-232.

da Costa Mendes, J., Oom do Valle, P., Guerreiro, M.M., \& Silva, J.A. (2010). The tourist experience: Exploring the relationship between tourist satisfaction and destination loyalty. Tourism: An International Interdisciplinary Journal, 58(2), 111-126.

Danurdara, A.B., \& Hidayah, N.U.R.D.I.N. (2016). Creating Customer Value and Its Implication To Customer Loyalty: An Empirical Study at Star Hotels in West Java, Indonesia. International Review of Management and Business Research, 5(2), $732-742$.

Edgell, D.L. (2019). Managing sustainable tourism: A legacy for the future. Routledge.

Gaffar, V., Wetprasit, P., \& Setiyorini, D. (2011). Comparative study of tourist characteristics on cultural heritage tourism sites: survey on tourist in Indonesia and Thailand heritage sites. Journal of Tourism, Hospitality \& Culinary Arts, 3(3), 53-68. http://ir.uitm.edu.my/id/eprint/44428

Gallarza, M.G., Ruiz-Molina, M.E., \& Gil-Saura, I. (2016). Stretching the value-satisfaction-loyalty chain by adding value dimensions and cognitive and affective satisfactions: A causal model for retailing, Management Decision, 54(4), 981-1003. https://doi.org/10.1108/MD-07-2015-0323

Giao, H.N.K., Vuong, B.N., Phuong, N.N.D., \& Dat, N.T. (2021). A model of factors affecting domestic tourist satisfaction on eco-tourism service quality in the Mekong Delta, Vietnam. GeoJournal of Tourism and Geosites, 36(2), 663-671. https://doi.org/10.30892/gtg.362spl14-696

González-Rodríguez, M.R., Díaz-Fernández, M.C., \& Font, X. (2020). Factors influencing willingness of customers of environmentally friendly hotels to pay a price premium. International Journal of Contemporary Hospitality Management, 32(1), 6080. https://doi.org/10.1108/IJCHM-02-2019-0147 
Hair, J.F., Hult, G.T., Ringle, C.M., \& Sarstedt, M. (2017). A Primer on Partial Least Squares Structural Equation Modelling (PLSSEM). Second Edition. SAGE Publications, Inc.

Henseler, J., Ringle, C.M., \& Sarstedt, M. (2015). A new criterion for assessing discriminant validity in variance-based structural equation modeling. Journal of the Academy Marketing Science. 43, 115-135. https://doi.org/10.1007/s11747-014-0403-8

Jaelani, A.K., Handayani, I.G.A.K.R., \& Karjoko, L. (2020). Development of tourism based on geographic indication towards to welfare state. International Journal of Advanced Science and Technology, 29(3s), 1227-1234.

Khuong, M.N. and Ha, T.T. (2014). The Influences of Push and Pull Factors on the International Leisure's Return Intention to Ho Chi Minh City. Vietnam - A mediation Analysis of Destination Satisfaction. International Journal of Trade, Economics and Finance, 5(6), 490-496. https://doi.org/10.7763/IJTEF.2014.V5.421.

Lee, S., Jeon, S., \& Kim, D. (2011). The impact of tour quality and tourist satisfaction on tourist loyalty: The case of Chinese tourists in Korea. Tourism Management, 32(5), 1115-1124. https://doi.org/10.1016/j.tourman.2010.09.016

Liang, H.C. (2008). Impact of Logistics Service Performance on Tourist Satisfaction and Loyalty. Doctoral Dissertation. RMIT University.

Liu, X., Dai, L., \& Derudder, B. (2017). Spatial inequality in the southeast Asian intercity transport network. Geographical review, 107(2), 317-335. https://doi.org/10.1111/j.1931-0846.2016.12181.x

Mohd Noor, N.H.H., Bakri, M.H., Wan Yusof, W.Y.R., Mohd Noor, N.R.A., \& Zainal, N. (2020).The Impact of the Bank Regulation and Supervision on the Efficiency of Islamic Banks. Journal of Asian Finance, Economics and Business, 7 (11), $747-757$. https://doi.org/10.13106/jafeb.2020.vol7.no11.747

Noor, N.H.H.M., Bakri, M.H., Yusof, W.Y.R.W., Noor, N.R.A.M., \& Abdullah, H. (2020). The Determinants of Bank Regulations and Supervision on the Efficiency of Islamic Banks in MENA Regions. Journal of Asian Finance, Economics and Business, 7 (12), $245-$ 254. https://doi.org/10.13106/jafeb.2020.vol7.no12.245

Nugroho, I., Pramukanto, F.H., Negara, P.D., Purnomowati, W., \& Wulandari, W. (2016). Promoting the rural development through the ecotourism activities in Indonesia. American Journal of Tourism Management, 5(1), 9-18. https://doi.org/10.5923/j.tourism.20160501.02

Ollivaud, P., \& Haxton, P. (2019). Making the most of tourism in Indonesia to promote sustainable regional development. OECD Economics Department Working Papers, No. 1535, OECD Publishing, Paris. https://doi.org/10.1787/c73325d9-en.

Prakash, M., \& Chowdhary, N. (2010). Tour guides: Roles, challenges and desired competences A review of literature. International Journal of Hospitality \& Tourism Systems, 3(1).

Rahman, A.N.H., Md Sahiq, A.N., Ismail, S., Bakri, M.H., \& Husin, A. (2016). Antecedents of a successful business venture for young entrepreneurs. Advanced Science Letters, 22(12), 4485-4488. https://doi.org/10.1166/asl.2016.8195

Rahmiati, F., Othman, N.A., \& Tahir, M.N.H. (2020). Examining the Trip Experience on Competitive Advantage Creation in Tourism. International Journal of Economics \& Business Administration (IJEBA), 8(1), 15-30.

Rahmiati, F., Othman, N.A., Bakri, M.H., Ismail, Y., \& Amin, G. (2020). Tourism Service Quality and Tourism Product Availability on the Loyalty of International Tourists. The Journal of Asian Finance, Economics and Business, 7(12), 959-968. https://doi.org/10.13106/JAFEB.2020.VOL7.NO12.959

Ramesh, V., \& Jaunky, V.C. (2021). The tourist experience: Modelling the relationship between tourist satisfaction and destination loyalty. Materials Today: Proceedings, 37 (2), 2284-2289. https://doi.org/10.1016/j.matpr.2020.07.723

Ramseook-Munhurrun, P., Seebaluck, V.N., \& Naidoo, P. (2015). Examining the structural relationships of destination image, perceived value, tourist satisfaction and loyalty: case of Mauritius. Procedia-Social and Behavioral Sciences, 175, $252-259$. https://doi.org/10.1016/j.sbspro.2015.01.1198

Ratminingsih, N.M., Suardana, M., \& Martin, A.A.N.Y. (2018). English for Tour Guide: A need Analysis of a contextual-based language teaching. In SHS Web of Conferences, 42, 00012. EDP Sciences. https://doi.org/10.1051/shsconf/20184200012

Richards, G. (2018). Cultural tourism: A review of recent research and trends. Journal of Hospitality and Tourism Management, 36, 1221. https://doi.org/10.1016/j.jhtm.2018.03.005

Salazar, N.B. (2013). Imagineering otherness: Anthropological legacies in contemporary tourism. Anthropological Quarterly, 86(3), 3669-696. https://www.jstor.org/stable/43652633

Sangpikul, A. (2018). The effects of travel experience dimensions on tourist satisfaction and destination loyalty: the case of an island destination. International Journal of Culture, Tourism and Hospitality Research, 12 (1), 106-123. https://doi.org/10.1108/IJCTHR-06-2017-0067

Sartorelli, M. (2019). Evolutionary patterns of the Chinese outbound travel market: opportunities and future perspectives. Bachelor's thesis, Università Ca'Foscari Venezia.

Setyanto, I., \& Pangestuti, E. (2019). Pengaruh komponen destinasi wisata (4a) terhadap kepuasan pengunjung pantai gemah tulungagung. Jurnal Administrasi Bisnis, 72(1), 157-167.

Stavrianea, A., \& Kamenidou, I.(E). (2021). Memorable tourism experiences, destination image, satisfaction, and loyalty: an empirical study of Santorini Island. EuroMed Journal of Business. https://doi.org/10.1108/EMJB-10-2020-0106.

Sumaedi, S., Bakti, I.G.M.Y., Astrini, N.J., Rakhmawati, T., Widianti, T., \& Yarmen, M. (2014). Public Transport Passengers' Behavioural Intentions: Paratransit in Jabodetabek-Indonesia. Springer Science \& Business Media.

Wahyuningsih (2012). The Effect of Customer Value on Behavioral Intentions in Tourism Industry. International Research Journal of Business Studies, 5 (1). https://doi.org/10.21632/irjbs.5.1.1-12

Wei, X., Meng, F., \& Zhang, P. (2017). Chinese citizens' outbound destination choice: Objective and subjective factors. International Journal of Tourism Research, 19(1), 38-49. https://doi.org/10.1002/jtr.2082

Xue, L., \& Yang, C. (2009). An Exploratory Study of Customer Satisfaction Based on ACSI Model: an application to the No.2 bus service in Gävle of Sweden (Dissertation). http://urn.kb.se/resolve?urn=urn:nbn:se:hig:diva-5621

Yamashita, R., \& Takata, K. (2021). Segmentation of active international sport tourists by destination loyalty. Journal of Sport \& Tourism. https://doi.org/10.1080/14775085.2021.1905051

Yasami, M., Promsivapallop, P., \& Kannaovakun, P. (2020). Food Image and Loyalty Intentions: Chinese Tourists' Destination Food Satisfaction. Journal of China Tourism Research, 1-21. https://doi.org/10.1080/19388160.2020.1784814

*** Economy Impact Reports. (2019). World Travel \& Tourism Council, (accessed on 4 February 2019). http://www.wttc.org 